\title{
Customer Relationship Marketing: Customer-Centric Processes for Engendering Customer-Firm Bonds and Optimizing Long-Term Customer Value
}

\author{
Namita Bhatnagar \\ Department of Marketing, I. H. Asper School of Business, \\ University of Manitoba, Winnipeg, \\ Canada
}

\section{Introduction}

Relationship marketing puts forward that firms' interactions with a variety of agents are part of an ongoing process (akin to a relationship) as opposed to being discrete transactional events (Morgan \& Hunt, 1994). Research within the area has examined interactions with numerous internal and external agents - such as, those that occur internally with employees (e.g., Arndt, 1983), within and across functional areas (e.g., Ruekert \& Walker, 1987) and business units (e.g., Porter, 1987), as well as externally with service providers (e.g., Moorman, Zaltman, \& Deshpande, 1992), suppliers (e.g., Frazier, Spekman, \& O’Neal, 1988), allied companies (e.g., Bucklin \& Sengupta, 1993), and customers (Berry, 1983). While a holistic conceptualization of relationship marketing encompasses a network of all relational exchanges relative to a firm (Morgan \& Hunt, 1994), a focus on profitable relationships with customers has gained traction as well as undergone transformation in recent years (Kumar \& Reinartz, 2006; Thomas, Reinartz, \& Kumar 2004).

Earlier research, particularly in the domain of services marketing, concerned itself with attracting, developing, and retaining customers as a means to creating customer equity (Berry 1983, p. 25; Berry \& Parasuraman 1991, p. 133). Moreover, retaining customers and sustaining long lasting relationships with them was argued as being more beneficial to firms than acquiring new customers (Bendapudi \& Berry, 1997). Many subsequent researchers in the area (e.g., Bhatnagar, Maryott, \& Bejou, 2007; Thomas, Reinartz, \& Kumar, 2004; Zeithaml, Rust, \& Lemon, 2001) have been more nuanced in their approach to customer relationships, and have grappled with: (a) understanding whether some customers are more valuable, and therefore better candidates for developing and maintaining relationships with than others, (b) identifying and developing metrics to help guide customer management decisions, and (c) determining the best methods for incorporating the tenets of customer relationship management (CRM) within marketing decision-making.

Overall, the aim of this chapter is to discuss: (1) what customer relationship management means, the evolution of the CRM concept, and the supporting role of information 
technology; (2) the need for indentifying, prioritizing, and selecting customers, and valuebased metrics for guiding these decisions; and (3) the application of CRM concepts in practice-e.g., with respect to understanding individual needs, and developing customized marketing mixes and loyalty programs that encourage volume and longevity. The need for understanding the role of customer emotions, incorporating hedonic appeals, and addressing privacy concerns that arise as a result of personalized CRM activities will also be discussed.

\section{Customer-centricity and the customer relationship management concept}

Putting customers and their needs at the centre of business thought processes and actions are fundamental aspects of marketing philosophy (Deshpande \& Webster, 1989). At the core of the customer relationship management concept is the related notion that customers are all individuals with unique needs, treating them as such is conducive to fostering long-term customer-firm bonds, and the appropriate development and management of these relationships is profitable to firms. Acting upon the CRM concept, however, can be challenging-especially in terms of understanding the individual needs of diverse customers, and creating customized products and services that meet these needs. As a result, companies often compromise by clustering people on the basis of their similarities on some behavioral, demographic, or psychographic characteristics. Standardized products/services that address the average needs of chosen customer segments are then created and marketed. Some difficulties standing in the way of true customization have been addressed by rapid advances made in the field of information technology since the mid-1990s. The wide availability of powerful IT products, coupled with wide Internet usage, has allowed companies to collect, store, and analyze vast amounts of behavioral and demographic data at the individual customer level, and to interact with customers directly (Moe \& Fader, 2001; Venkatesan \& Kumar, 2003). At the same time, increased flexibility in production processes has made it possible to act upon this customer knowledge by developing individualized products with greater ease.

Companies have utilized information contained within these rich customer databases in different ways as the concept of CRM itself has evolved (Kumar \& Reinartz, 2006; p. 20-22). In the early stages, customer data was used for the purpose of automating sales force processes (e.g., with respect to identifying prospective leads, telemarketing, generating product/service quotations, and placing orders prior to actual sales) and providing customer service and support (e.g., with respect to help desk and field support after a sale). These two processes occurred independently of each other for the most part. In the next phase, data was used cohesively across all customer-oriented activities engaged in by a firm regardless of whether they occurred prior to, during, or after a sales transaction. In the current stage, it is advocated that customer data be used strategically such that all frontfacing customer functions become integrated with the back-end systems of the firm and its' network of suppliers and partners. The end goal is to maximize customer value. This evolution in CRM permits the notion to be embedded again within the broader relationship marketing concept that is holistic in nature, and considers the entire network of ongoing relational exchanges a focal firm is engaged in.

It is also worth mentioning that CRM activities are all too often confused by managers as being mere technological projects that are associated with particular software and 
techniques. Although IT systems play a crucial role in the implementation phase, it must be emphasized that the contemporary notion of CRM is integrative in nature whereby all of a firms' functions and processes are strategically focused on providing customers value and receiving value from them in return. CRM is therefore also defined as "the practice of analyzing and utilizing marketing databases and leveraging communication technologies to determine corporate practices and methods that will maximize the lifetime value of each customer to the firm" (Kumar \& Reinartz, 2006, p.17). The idea of customer lifetime value is of particular importance to contemporary customer management decisions, and will be discussed in greater detail within the context of value-based metrics for customer identification, prioritization, and selection.

\section{Customer identification and prioritization}

Many marketers believe that resources of a company should be invested in developing and maintaining relationships with customers over an extended period of time, and posit a positive association between customer duration and firm performance (Morgan \& Hunt, 1994; Reichheld, Markey, \& Hopton, 2000; Sheth \& Parvatiyar, 1995). The proposed advantages of customer retention and long lasting relationships are contended on several fronts-for example, in terms of (a) generation of recurring business, (b) higher expenditures per period, (c) lower price sensitivity (and the concomitant ability of sellers to charge higher prices), (d) lower costs of servicing, (e) greater dissemination of positive word-of-mouth to other potential prospects, and (f) higher forgiveness for poor service from customers of long standing than newer ones (Bendapudi \& Berry, 1997; Reichheld et al., 2000). In other words, customers' contributions to firm profitability increase as initial acquisition costs are recouped and the ongoing marginal costs of maintaining them are outweighed by the marginal benefits accrued over time.

A consequence of arguments supporting customer longevity has been the proliferation of expensive 'customer loyalty programs' that provide primarily economic/utilitarian incentives for generating patronage and repeat business (e.g., the Air Miles program and other frequency marketing programs). There is scant empirical evidence, however, that backs up the arguments put forth in favor of customer retention as well as for the positive impact of loyalty programs on corporate bottom lines. In fact, Reinartz and Kumar (2000) used a broad-based sample of individual customers across four industries to demonstrate that customers of longer standing who are not bound by a contract don't necessarily pay price premiums, nor are cheaper to service, as compared to shorter term customers.

Researchers such as Dowling and Uncles (1997) have also questioned assertions pertaining to the benefits of customer retention, and called for rigorous testing of the customer longevity-profitability relationship. While it is true that some customers of long standing may display the beneficial characteristics proposed above, this may not always hold true. For instance, patrons that are regulars may also be demanding in terms of the service and support levels sought, as well as the price-points that they consider as acceptable. The cost of supporting such clients may very well exceed the revenue that they bring in, ultimately making them unprofitable to pursue. On the other hand, there may also be customers that are very profitable, but the business generated takes place only for a short period (Thomas et al., 2004). In addition to issues of duration, customers can also be targeted in order to shore up market share and gain a competitive edge-there are segments, however, that 
while boosting market share are unprofitable to serve (Rust, Lemon, \& Zeithaml, 2001; Thomas et al., 2004; Zeithaml et al., 2001). Despite the numerous arguments put forth for increasing customer duration, as well as various strategies suggested for doing so (Bolton \& Lemon, 1999), more recent research recommends the optimization of customer value and profitability regardless of loyalty, duration, or market share concerns (e.g., Kumar \& Reinartz, 2004; Rust et al., 2001; Thomas et al., 2004; Venkatesan \& Kumar, 2003; Zeithaml et al. 2001). A shift has therefore occurred from focusing on customer longevity and developing relationships with all customers to customer value and developing relationships with the right ones - i.e., those that are profitable and are therefore of value to the firm (Thomas et al., 2004; Venkatesan \& Kumar, 2003).

Target marketing usually involves market segmentation on the basis of one or more characteristics (e.g., those that are demographic, behavioural, psychographic, and/or geographic in nature), choosing segments to target by matching the average needs of the various segments with the company's ability and willingness to fulfill them, and creating marketing mixes that satisfy the average needs of the target segments. Also using segment profitability - a variable not typically considered within targeting decisions (Zeithaml et al., 2001) - would allow firms to be more pragmatic about identifying and selecting the most promising customers. Therefore, where the aim earlier was to instigate and manage relationships with all current and potential customers, the aim now is to create typologies of customers on the basis of their profitability to the firm and expend resources on differentially serving and satisfying them. Offering a differentiated mix of products and services is justified by researchers such as Zeithaml et al. (2001) who argue that more valuable customers respond most positively to service quality enhancements and other marketing efforts. The vast amounts of detailed demographic and behavioral customer data amassed by marketers are being used for predicting the potential profitability of individual customers, and are the backbone of direct marketing and database marketing initiatives. A number of metrics have been developed to help categorize customers in terms of their value to the firm. Descriptions of some key metrics - specifically SOW, RFM and CLV techniques, as well as discussions related to their strong points and shortcomings, are provided next

\subsection{Value-based metrics for customer identification, prioritization, and selection}

Marketers use individual response data contained within customer databases within a variety of computations in order to gauge customer value. Popular proxies for customer worth include the SOW, RFM, and CLV scores that are used for ranking customers from most to least valuable. A firm's importance to its customers is often assessed via the share of wallet (SOW) it occupies in relation to its competitors. Customers' SOW scores are simply their expenditures on a particular brand relative to expenditures on all brands within the category. The greater the share of wallet occupied by a brand, the more valuable that customer is deemed within the customer relationship management framework. A weighted combination of transaction recency (i.e., how recently a customer last transacted with a firm), frequency (i.e., how often transactions occur within the pertinent time frame), and monetary value (i.e., the average expenditure during this period) yields a customers' RFM score. Different researchers attach greater or lesser importance to the different facets of customer value. For example, the greatest weightage is typically given to the recency of transactions and the least to the frequency with which they occur (Aaker, Kumar, \& Day, 1998; Kumar, 
Ramani, \& Bohling, 2004). On the other hand, Venkatesan and Kumar (2003) consider frequency as being more important than the average monetary value of transactions.

These customer-valuation techniques, though used often as indicators of relative loyalty and intensity of attachment, have been associated with shortcomings that include the use of average values (that do not adjust for demand fluctuations), and the use of data generated from existing customers (that does not account for prospective customers). The main critique of these approaches, however, centers on their backward-looking historical perspective of buyer behavior. Predictions about future consumption patterns based on extrapolations of past results run into difficulties such as the inability to create distinctions between customers that have transacted heavily in the past but may or may not continue to do so in the future. Consequently, customer lifetime valuation (CLV) techniques that account for differences in purchase and attrition patterns and predict future consumption are often suggested as forward-looking probabilistic alternatives for replacing or augmenting the SOW and RFM metrics (Kumar et al., 2004; Venkatesan \& Kumar, 2003).

Customer lifetime value refers to the net present value of a customer to the firm-i.e., the present value of revenues less expenditures associated with a customer over their lifetime with the firm. While individual CLV aids in customer prioritization and selection decisions (Kumar et al., 2004), CLV is often aggregated (Berger \& Nasr, 1998; Gupta, Lehmann, \& Stuart, 2004) and represents the overall equity inherent within a market segment (Kumar et al., 2004).

\subsection{Managing relative investments in customer acquisition and retention to maximize customer value}

Customer value maximization implies generating the most amount of customer revenue while minimizing associated marketing expenditures (Rust, Moorman, \& Dickson, 2002). Managers must often decide amongst competing resource allocation needs related to all the elements of the marketing mix. For example, Berger and Nasr-Bechwati (2001) and Murthy and Mantrala (2005) examine budget allocation decisions between different types of promotional activities. Along similar lines, investments on customer acquisition must be weighed against investments on customer retention, and vice versa. It is widely assumed that existing customers should be maintained as it is less expensive to retain customers than acquire new ones. Pfeifer (2005) however finds that firms do not necessarily spend more on customer acquisition as compared to retention.

Optimal resource allocation (ORA) models have been developed within marketing in order to provide guidance for an optimal blend of investments across customer acquisition and retention activities such that the value of the customer base is maximized (e.g., Berger, Bolton, Bowman, Briggs, Kumar, Parasuraman, \& Terry, 2002; Blattberg \& Deighton, 1996; Pfeifer, 2005; Thomas et al., 2004). The backward-looking (SOW and RFM) and forwardlooking value metrics (CLV) described previously often guide resource allocation decisions. For instance, Venkatesan and Kumar (2003) modeled data within the high-tech computer industry and recommended reserving the highest level of service for customers high on backward as well as forward measures of value, and the lowest investments for those low on both. They also suggested using strong persuasive tactics for customers with high future potential despite low prior profitability, and interacting with customers that were profitable in the past but are low on forward metrics solely via low-cost means. 
Researchers such as Jain and Singh (2002) and Thomas et al. (2004) caution that optimal resource allocation models should not seek to optimize acquisition and retention costs in an isolated fashion. Rather, they advise incorporating both types of expenditures at the same time in order to assess their joint impact on profitability - an approach reflective of what actually takes place in practice.

\section{Applying the CRM concept}

Companies collect and store detailed data pertaining to existing and prospective customers within vast databases, conduct data analysis in order to better understand each customer, and implement marketing initiatives and CRM programs to pursue individualized profitable relationships with customers. CRM strategies can occur along all dimensions of the marketing mix (Kumar \& Venkatesan, 2005; Murthy \& Mantrala, 2005; Rust et al., 2001). For example, products and services can be tailored, as can pricing, channels of distribution, and promotional methods to suit the unique needs and profile of each customer. CRM strategies are often implemented in the form of customer loyalty programs that are discussed in greater detail here.

Loyalty marketers offer some form of benefits to customers with the goal of instigating greater expenditures and repeat purchases, deeper customer-firm bonds, and lower defection rates (Uncles, Dowling, \& Hammond, 2003). Loyalty programs came about within the travel industry in the 1980s, gained traction in the midst of the information technology boom of the 1990s, and have now attained ubiquity (Capizzi \& Ferguson, 2005). Programs in a variety of formats exist world-wide in consumer-to-business contexts (e.g., airline frequent flier programs, the Canadian Air Miles coalition, grocery store frequent shopper programs, rewards programs associated with credit cards, and so forth) as well as business-to-business settings (e.g., within the technology and telecommunications sectors; Capizzi \& Ferguson, 2005). Berman (2006) reports that the vast majority (90\%) of Americans belong to at least one of more than 2000 such programs that exist within the US (c.f. Mimouni-Chaabane \& Volle, 2010). Kumar and Reinartz (2006) designate loyalty programs as a "CRM tool to identify, reward, and retain profitable customers". Most literature within the area has looked at firms' motivations in terms of creating relational bonds with customers (e.g., Lewis, 2004), and primarily economic gains that customers receive from participating in such programs (Peterson, 1995). More recent research, however, suggests greater variation in customers' motivations for participation (Mimouni-Chaabane \& Volle, 2010) - for example, convenience and cost savings (economic/utilitarian benefits), experiencing enjoyment/entertainment (hedonic benefits), and receiving recognition for intensity of patronage (symbolic benefits). Capizzi and Ferguson (2005) recommend that creativity, innovation, and imagination augment the ubiquitous and largely indistinguishable programs that are developed around financial incentives. Recently, loyalty programs have indeed evolved to include benefits that go well beyond those that are merely economic and utilitarian in nature (e.g., preferential treatment given to Ralph Lauren priority VIP customers, and to frequent fliers within American Airline's AAdvantage program; Mimouni-Chaabane \& Volle, 2010).

Loyalty programs are expensive to run, and questions pertaining to their effectiveness frequently crop up in customer management literature (e.g., Fournier 1998; Kumar \& Reinartz, 2006; Uncles et al. 2003). Uncles et al. (2003) argue that pressures to maintain competitive parity rather than clear cut empirical evidence of a positive relationship with 
profitability often motivate firms to institute and maintain loyalty programs. Fournier (2006) suggests that an inadequate grasp of the true meaning of loyalty itself, and not poor managerial implementation, contributes to the lack of success of loyalty marketing. In the literature, loyalty is conceptualized in several ways: such as, on the basis of attitudes ("a consistently favorable set of stated beliefs towards the brand"; Uncles et al 2003, p. 296), behaviors ("measured by repeat purchase"; p. 297), or a combination thereof (Fournier, 1998). Earlier emphasis by relationship marketers on customer longevity was manifested in a concomitant emphasis on the behavioral notion of loyalty in practice where largely utilitarian incentives (e.g., discounts, cash back, and bonus points) were offered for engaging in repeat purchases. Repeat purchases, however, can be an external expression of inertia and habit, just as much as loyalty which implies a deep emotional connection. Moreover, just as there are many types of transactional and/or emotional relationships that can occur in the interpersonal domain, customer can also have different types of relational bonds with companies (Fournier, 1998). The focus is therefore shifting to engendering not just utilitarian but also a variety of hedonic and symbolic motivations for loyalty program participation.

The reliance on customer-specific data for designing customized loyalty programs also raises the issue of infringements on customer privacy. Selling customer data for the purposes of data-mining and customer profiling is a lucrative revenue stream for many retailers and service providers. For instance, many leading US banks and credit/debit card issuers (e.g., Wells Fargo, Citibank, Discover) sell information related to their customers' shopping habits (e.g., where they shop, how much they spend, the frequency with which this occurs) to merchants that use this data to profile customers and design targeted deals. The financial institutes then act as intermediaries for extending the personalized offerings to customers. Although the banks claim that sensitive customer information such as bank account numbers and Social Security numbers aren't disclosed to the merchants and customers benefit from relevant deals, the automatic opt-in for such loyalty programs (despite the government mandated option to opt out) constitutes an area of deep concern for customers and consumer privacy advocates (Ellis, 2011). The push to provide personalized experiences that rely heavily on past consumption histories can also lead to unintended breaches of privacy and negative consequences in the domain of publicly consumed products and services. Wan, Bhatnagar and Qiu (2008) find that customers whose impression management goals are subverted by disclosures of past consumption patterns respond with feelings of embarrassment, less favorable attitudes toward the service episode, and lowered intentions of future patronage.

Companies as well as customers benefit from fostering emotional connections with each other. This is however subject to caveats wherein hedonic and symbolic benefits and not mere financial benefits are perceived by customers, and private boundaries are not breached in a bid to profile individual customers.

\section{Conclusion}

Conventional customer relationship management wisdom suggested that customers of longer standing provide a number of benefits (such as, lower price sensitivity and cost of serving) that are not as forthcoming from those of shorter tenure. Firms therefore expended resources on creating relational bonds with customers with the intent of retaining them over 
the long-term. This focus on establishing relationships in a generic fashion with all customers has given way to more targeted retention efforts where bonds are sought with higher value (i.e., profitable) customers. The contemporary CRM concept is holistic and encompasses the network of relational exchanges a firm engages in internally as well as externally (with customers, suppliers, and other partners) with the end-goal of maximizing customer value.

Numerous backward (e.g., SOW and RFM scores) and forward looking metrics (e.g., CLV scores) have been developed for gauging customer value, and a combination of both (but especially forward looking CLV metrics) is recommended for identifying and selecting customers with high future potential. Loyalty programs that provide a variety of benefits to customers for intensifying consumption and re-patronage have evolved on two fronts: first, on the basis of providing differential rather than generalized treatment to customers of varying worth, and second, on the basis of the types of benefits offered spanning the spectrum of economic and utilitarian incentives, emotional and experiential incentives, and symbolic incentives that provide recognition and social rewards for greater consumption. Information systems play the essential supporting role of data collection, storage, and analysis required within CRM programs for understanding and interacting with individual customers. At the same time, customer data must be used with care as the access to and use of detailed customer information leaves the relationship marketing industry open to criticisms from customer advocates that fear the loss of privacy.

\section{References}

Aaker, D.A., Kumar V., \& Day, G. S. (1998). Marketing research. New York: John Wiley \& Sons.

Arndt, J. (1983). The political economy paradigm: Foundation for theory building in marketing. Journal of Marketing, 47 (Fall), 44-54.

Bendapudi, N., \& Berry, L.L. (1997). Customers' motivations for maintaining relationships with service providers. Journal of Retailing, 73 (1), 15-37.

Berger, P. D., Bolton, R. N., Bowman, D., Briggs, E., Kumar, V., Parasuraman, A., \& Terry, C. (2002). Marketing actions and the value of customer assets: A framework for customer asset management. Journal of Service Research, 5 (1), 39-54.

\& Nasr, N. I. (1998). Customer lifetime value: Marketing models and applications. Journal of Interactive Marketing, 12 (Winter), 17-30.

, \& Nasr-Bechwati, N. (2001). The allocation of promotion budget to maximize customer equity. The International Journal of Management Science, 29, 49-61.

Berman, B. (2006). Developing an effective customer loyalty program. California Management Review, 49 (1), 123-148.

Berry, L. (1983). Relationship marketing. In Emerging Perspectives on Services Marketing, L. Berry, G. L. Shostack, \& G. D. Upah, eds., Chicago: American Marketing Association, 25-28.

\& Parasuraman, A. (1991). Marketing Services. New York: The Free Press.

Bhatnagar, N., Maryott, K., \& Bejou, D. (2007). Customer selection and prioritization: The optimal resource allocation approach to maximizing customer value. Journal of Relationship Marketing, 6 (3/4), 117-130. 
Blattberg, R. C., \& Deighton, J. (1996). Manage marketing by the customer equity test. Harvard Business Review, (July-August), 136-144.

Bolton, R. N., \& Lemon, K. N. (1999). A dynamic model of customer's usage of services: Usage as an antecedent and consequence of satisfaction. Journal of Marketing Research, 36 (May), 171-186.

Bucklin, L. P., \& Sengupta, S. (1993). Organizing successful co-marketing alliances. Journal of Marketing, 57 (April), 32-46.

Capizzi, M. T., \& Ferguson, R. (2005). Loyalty trends for the twenty-first century. Journal of Consumer Marketing, 22 (2/3), 72-80.

Deshpande, R., \& Webster, Jr., F. E. (1989). Organizational culture and marketing: Defining the research. Journal of Marketing, 53 (1), 3-15.

Dowling, G. R., \& Uncles, M. (1997). Do customer loyalty programs really work?. Sloan Management Review, 38 (Summer), 71-82.

Ellis, B. (2011). Banks' billion-dollar idea: Sell your shopping data. Retrieved from www.CNN.com on July 62011.

Fournier, S. (1998). Consumers and their brands: Developing relationship theory in consumer research. Journal of Consumer Research, 24 (4), 343-373.

Frazier, G. L., Spekman, R. E., \& O'Neal, C. R. (1988). Just-in-time exchange relationships in industrial markets. Journal of Marketing, 52 (October), 52-67.

Gupta, S., Lehmann, D., \& Stuart, J. (2004). Valuing customers. Journal of Marketing Research, 41, 7-18.

Jain, D., \& Singh, S. S. (2002). Customer lifetime value research in marketing: A review and future directions. Journal of Interactive Marketing, 16 (2), 34-46.

Kumar, V., Ramani, G., \& Bohling, T. (2004). Customer lifetime value approaches and best practice applications. Journal of Interactive Marketing, 18 (3), 60-72.

Kumar, V. \& Reinartz, W. J. (2006). Customer Relationship Management: A Databased Approach. John Wiley \& Sons, Inc.

Kumar, V., \& Venkatesan, R. (2005). Who are the multichannel shoppers and how do they perform?: Correlates of multichannel shopping behavior. Journal of Interactive Marketing, 19 (2), 44-62.

Lewis, M. (2004). The influence of loyalty programs and short-term promotions on customer retention. Journal of Marketing Research, 41 (3), 281-292.

Mimouni-Chaabane, A., \& Volle, P. (2010). Perceived benefits of loyalty programs: Scale development and implications for relational strategies. Journal of Business Research, 63, 32-37.

Moe, W. W., \& Fader, P.S. (2001). Uncovering patterns in cyber shopping. California Management Review, 43 (4), 106-117.

Moorman, C., Zaltman, G., \& Deshpande, R. (1992). Relationships between providers and users of marketing research: The dynamics of trust within and between organizations. Journal of Marketing Research, 29 (August), 314-329.

Morgan, R. M., \& Hunt, S. (1994). The commitment-trust theory of relationship marketing. Journal of Marketing, 58 (July), 20-38.

Murthy, P., \& Mantrala. M. K. (2005). Allocating a promotion budget between advertising and sales contest prizes: An integrated marketing communications perspective. Marketing Letters, 16 (1), 19-35. 
Peterson, R. A. (1995). Relationship marketing and the consumer. Journal of the Academy of Marketing Science, 23 (4), 278-281.

Pfeifer, P. E. (2005). The optimal ratio of acquisition and retention costs. Journal of Targeting, Measurement and Analysis for Marketing, 13 (2), 179-188.

Porter, M. E. (1987). From competitive advantage to corporate strategy. Harvard Business Review, 65 (May/June), 43-59.

Reichheld, F. F., Markey Jr., R. G., \& Hopton, C. (2000). The loyalty effect-The relationship between loyalty and profits. European Business Journal, 12 (3), 134.

Ruekert, R., \& Walker, O. (1987). Marketing's interaction with other functional units. Journal of Marketing, 51 (January), 1-19.

Rust, R. T., Lemon, K.N., \& Zeithaml, V.A. (2001). Where should the next marketing dollar go? Marketing Management, 10 (3), 24-28.

Moorman, C., \& Dickson, P. R. (2002). Getting return on quality: Revenue expansion, cost reduction, or both. Journal of Marketing, 66 (4), 7-24.

Sheth, J. N., \& Parvatiyar, A. (1995). Relationship in consumer markets: Antecedents and consequences. Journal of the Academy of Marketing Science, 23 (4), 255-271.

Thomas, J. S., Reinartz, W., \& Kumar, V. (2004). Getting the most out of all your customers. Harvard Business Review, July-August, 116-123.

Uncles, M. D., Dowling, G. R., \& Hammond, K. (2003). Customer loyalty and customer loyalty programs. The Journal of Consumer Marketing, 20 (4/5), 294-316.

Venkatesan, R., \& Kumar, V. (2003). Using customer lifetime value in customer selection and resource allocation. MSI Reports, Working Paper Series, 3, 3-27.

Wan, F., Bhatnagar, N., \& Qiu, P. (2008). All friendliness Is not created equal: The role of impression management goals and server connectedness in consumer embarrassment and service experience. Competitive Paper, Society for Consumer Psychology Conference, February, New Orleans, LA.

Zeithaml, V. A., Rust, R. T., \& Lemon, K. N. (2001). The customer pyramid: Creating and serving profitable customers. California Management Review, 43 (4), 118-142. 


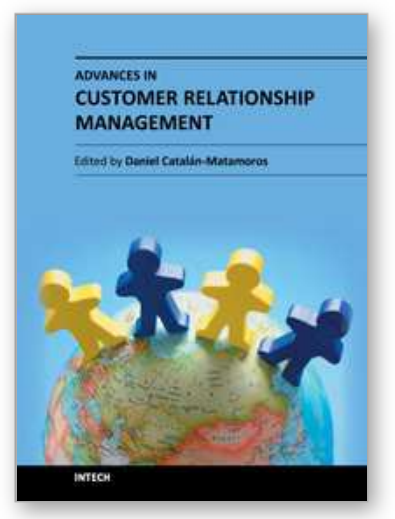

\author{
Advances in Customer Relationship Management \\ Edited by Dr. Daniel Catalan-Matamoros
}

ISBN 978-953-51-0516-9

Hard cover, 146 pages

Publisher InTech

Published online 11, April, 2012

Published in print edition April, 2012

Customer relationship management (CRM) strategies have become increasingly important worldwide due to changes in expectations from customers as well as changes in the nature of markets. This book puts forth a conceptualization that attempts to not only outline CRM's domain but also to reconcile the divergent perspectives found in the academic and popular literature. Readers can see through measurable datacontaining examples how the theory is applied with great success by various real-life examples. This book presents innovative proven methods for determining whether a CRM strategy for changing the way a company provides service (by adding new technology, processes, and procedures) will realize the return on the investment projected. It could be a great help to CRM personnel, student, managers and any one that works directly or indirectly with customers.

\title{
How to reference
}

In order to correctly reference this scholarly work, feel free to copy and paste the following:

Namita Bhatnagar (2012). Customer Relationship Marketing: Customer-Centric Processes for Engendering Customer- Firm Bonds and Optimizing Long-Term Customer Value, Advances in Customer Relationship Management, Dr. Daniel Catalan-Matamoros (Ed.), ISBN: 978-953-51-0516-9, InTech, Available from: http://www.intechopen.com/books/advances-in-customer-relationship-management/an-overview-ofrelationship-marketing-resource-allocation-decisions-loyalty-and-emotions-in-optimizi

\section{INTECH}

open science | open minds

\section{InTech Europe}

University Campus STeP Ri

Slavka Krautzeka 83/A

51000 Rijeka, Croatia

Phone: +385 (51) 770447

Fax: +385 (51) 686166

www.intechopen.com

\section{InTech China}

Unit 405, Office Block, Hotel Equatorial Shanghai

No.65, Yan An Road (West), Shanghai, 200040, China 中国上海市延安西路65号上海国际贵都大饭店办公楼 405 单元

Phone: +86-21-62489820

Fax: $+86-21-62489821$ 
(C) 2012 The Author(s). Licensee IntechOpen. This is an open access article distributed under the terms of the Creative Commons Attribution 3.0 License, which permits unrestricted use, distribution, and reproduction in any medium, provided the original work is properly cited. 